\title{
Stoneware Jars from the 18th Century from the Saxon Palace in Warsaw
}

\author{
Ewelina Więcek-Bonowska ${ }^{a}$
}

\begin{abstract}
The article presents a unique set of 18th century apothecary vessels related to the Warsaw court of the Electors of Saxony. The stoneware jars were excavated at the site of the former Saxon Palace in Warsaw between 2006 and 2008. The collection, consisting of seven intact or almost completely-reconstructable specimens, is a unique find in Warsaw and in Poland. The article describes the vessels (their form, decoration and dimensions) and discusses their possible function (storing medicines used by the Saxon court). The study enlarges our limited knowledge about the material aspects of medicine in the Polish capital in the Modern period.
\end{abstract}

KEY-WORDS: Saxon Palace, Warsaw, Augustus II the Strong, Augustus III, drug jars, stoneware jars, 18th century

\section{INTRODUCTION}

The specimens were discovered during archaeological and architectural work carried out in 2006 under the supervision of Ryszard Cędrowski (Cędrowski 2006). The examined area encompassed the centre of the western frontage of Piłsudski Square in Warsaw.

The buildings of the Saxon Palace (Polish: Patac Saski) stood in this place until the Second World War. In I7I3, King Augustus II bought an estate originally owned by Andrzej Morsztyn and in the same year ordered the construction of a line of parks and palaces linking the western outskirts of Warsaw with the Vistula River. This urban feature is known as the Saxon Axis (Polish: Oś Saska); the Saxon Palace was its main part. It was one of the greatest achievements of Polish town planning in the I8th century, an expression of the absolutist ambitions of Augustus II the Strong, who wanted to commemorate his reign by erecting a personal residence in the Polish capital. Before 1713 , the area chosen for the construction of the Saxon Axis was filled with chaotically-arranged buildings of little architectural value, most of which were demolished to create an area resembling a pentagonal fan (Kowalczyk 1997: 39).

a Museum of Warsaw, Old Town Market Square 28-42, oo-272 Warsaw; e-mail: ewelina.wiecek@ muzeumwarszawy.pl; https://orcid.org/oooo-0002-472I-508X 
96 Ewelina Więcek-Bonowska

The construction of the Saxon Axis could be divided into three stages. The first one lasted from 1713 to the beginning of the 1720 . During this period, two estates were merged, the above-mentioned Morsztyn estate and the Tarło family estate, acquired in I714. Along with the existing Baroque (Morsztyn's) palace, the Saxon Garden was designed and created; it was approximately 340 metres long. The next stage lasted until the death of Augustus II in I733. Other parcels of land adjoining the King's estate were purchased at that time. After all the plots of land had been merged, the urban layout corresponding to the final form of the Saxon Axis was created. In I72I, the estate of the Sanguszko family was acquired (later transformed into the Brühl Palace), and in 1726, the residence of Bishop Teodor Potocki was attached, later transformed into the Blue Palace (Polish: Pałac Btękitny), built for Anna Orzelska, daughter of Augustus II.

The main part of the work leading to the construction of the Saxon Axis was the construction of the palace itself, designed by two architects - Carl Friedrich Pöppelman and Joachim Daniel Jauch. To the east of the residence, a trapezoidal courtyard was built, widening towards Krakowskie Przedmieście Street. The northern and southern sides of the courtyard were surrounded by walls. In the garden, at the meeting point of five main arteries, a pavilion called the Great Salon was built in 1724. The construction of the palace in the second stage of the development of the Saxon Axis was erratic, especially towards the end, mainly because of lack of funds. The project, interrupted by the death of Augustus II, was continued by his son, Augustus III, who was elected King of Poland in I733. In the I730s and I740S, the last stage of the development of the Saxon Axis took place. Huge wings were added to the palace at the side of the courtyard and smaller ones on the garden side. The courtyard was widened and given a rectangular shape. In its eastern part, auxiliary buildings were erected, occupied by forges and palace stables.

In 2008, the area adjacent to and partially extending to the outskirts of the southern wing of the former Saxon Palace was examined archaeologically (Cędrowski 2008). The excavations were intended to precede the rebuilding of the palace. The reconstruction plan has not been implemented so far, but the preliminary research made it possible to discover numerous relics of the past; the results of the excavations shed light on some of the questions relating to the Saxon Palace, its surroundings and inhabitants.

Most of the artefacts were found in the northern wing of the former palace in two places interpreted as garbage dumps. They were used at the end of the i8th century. There had been latrines in this place earlier. Artefacts from I8th and early igth centuries were found on Level V in several layers (mainly Layer 66). One jar was discovered in Zone E (southern wing).

The unearthed specimens have so far-been discussed in a limited number of scholarly studies (Więcek 20I2; Klarecki 20I7), two popular books (Borowska 2009; 2020) and several articles (Klarecki 2008; Borowska 20II-2OI2; 20I8; 20I9a; 20I9b; 2019c) describing the discoveries made between 2006 and 2008 (Cędrowski 2007). Regrettably, no monograph of the excavation site has been published so far. 


\section{JARS}

Stoneware jars were among nearly 8000 items found in the garbage dumps on the site of the former Saxon Palace. The intact specimens, almost complete ones and those that could be reconstructed form a group consisting of seven pieces. Apart from complete specimens, plentiful stoneware sherds were discovered; they indicate the presence of a large number of stoneware vessels at the site. The total number of this type of vessels is 20 .

All the jars are almost identical. They have wide, flaring mouths and are incised with horizontal, circumferential lines. The cross-section of the vessels is square in the middle of their height and circular at the base, which is sometimes slightly concave, sometimes flat - usually with cutting-off marks. Often the colour of the body is not uniform, e.g., cream-gray. The vessels are covered with salt glaze. Their height varies between $2 \mathrm{I}$ and $23 \mathrm{~cm}$, the diameter of the mouth is between 7.8 and $8.3 \mathrm{~cm}$, the base diameter between 7.8 and $9 \mathrm{~cm}$ and the width in the middle of their height between 9.6 and $10.3 \mathrm{~cm}$ (Fig. I).

The royal monogram of the Saxon rulers of Poland - crowned, intertwined letters "AR" - is incised on one side of the vessels (Fig. I). The monogram on the jars is exactly
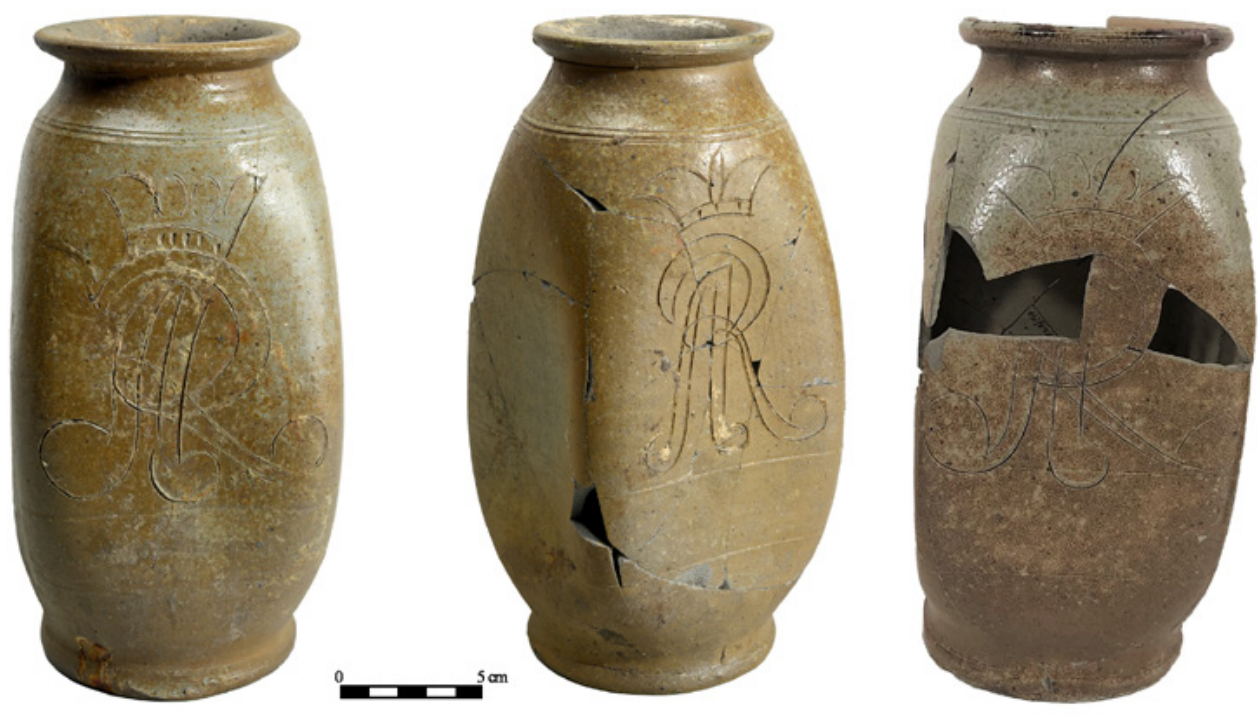

Fig. 1. Stoneware jars from the Saxon Palace in Warsaw. Photo by G. Kułakowska. 
98 Ewelina Więcek-Bonowska

the same as the monogram on Saxon postal mileposts. ${ }^{1}$ Two horizontal, circumferential lines are incised below the royal monogram, approximately $2 \mathrm{~cm}$ apart. It is possible that they mark capacities, as in the case of measuring vessels (Kluttig-Altman 2006: 324).

\section{ANALOGIES}

I have not been able to find direct analogies to the jars from the Saxon Palace among the published excavation finds either from Warsaw, Poland and the Europe. Many vessels of similar shape have been discovered, but they are made of different materials (glass, metal and also pottery, but of a different ceramic composition), as well as vessels of the same material (stoneware), but of different shapes.

Additional difficulties are caused by the inadequate state of research of modern pottery excavated in Poland, especially stoneware, and scarcity of sources dealing with the history of pharmacy. Publications about stoneware usually focus on tableware and richly-decorated specimens, devoting little attention to storage vessels (for example Dąbal 20I2). Most studies related to the history of pharmacy describe glass artefacts, less often mentioning other objects, including pottery (for example Kozłowska and Nowakowski 1987; Więcek M. 20I7).

Stoneware jars similar in shape to those described in the present study were found in the Wisłoujście Fortress in Gdańsk (Dąbal 20I5: 252). These vessels are $23 \mathrm{~cm}$ high, with a mouth diameter of $17 \mathrm{~cm}$. However, their rims have seatings for lids, absent in the specimens from the Saxon Palace. The fragmentary preservation of the finds from Gdańsk makes it impossible to reconstruct their exact shape (Dąbal 20I5: 252).

In the city of Gdańsk, during excavations at Świętojańska Street No. 6-7, a ceramic vessel was discovered. This was "made of white clay and its firing technique resembled the technique used to manufacture stoneware vessels" (Dąbal et al., 2018b: 242, Fig. 2). The archaeological context indicates that this small jar may date from the end of the I8th century or the beginning of the 19th century. The authors of the study remark that this specimen appears to be an imitation of stoneware vessels.

At another excavation site in Gdańsk - in the area of the former slaugterhouse - stoneware vessels made in Duingen and Coppengrave were found; they are interpreted as storage and apothecary vessels. The author of their study notes that they are similar to I8th-century specimens, so probably should be dated accordingly (Dąbal 20I8: 320, Fig. 2I).

Stoneware jars interpreted as storage vessels, produced in England, were also found on board of the wreck of The General Carleton, a British ship that sank in the Baltic in

Bernd Brinkmann, oral communication (October 24, 2020). 

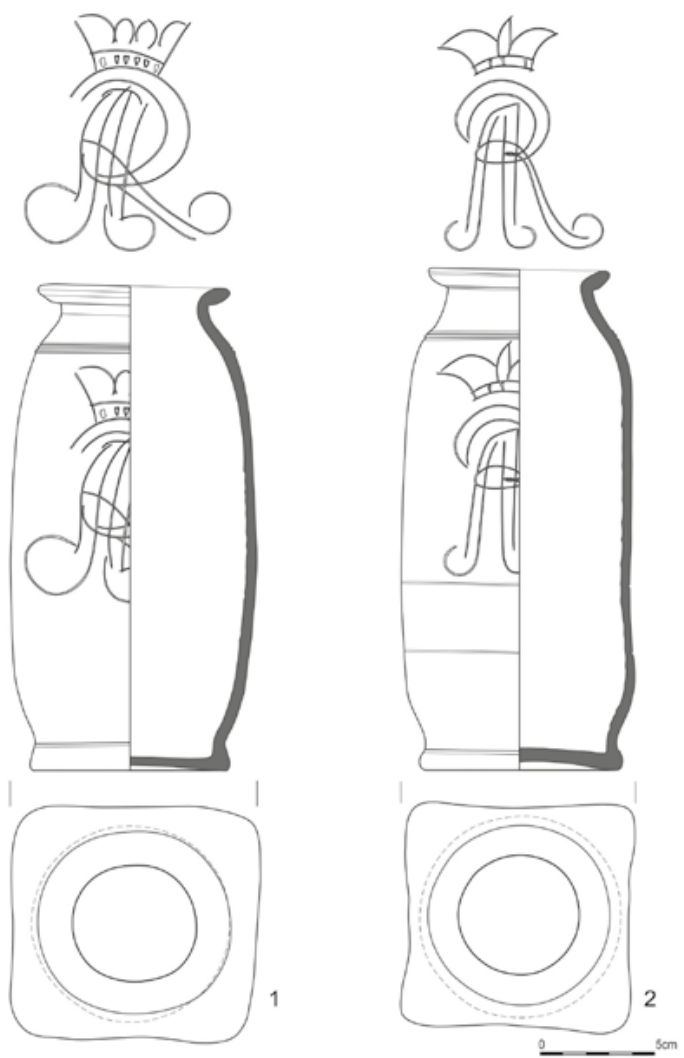

Fig. 2. Stoneware jars from the Saxon Palace. Drawing by U. Skwara-Nieckuła.

I785 near the present-day Polish coast. They came in two sizes: larger $(17.5 \mathrm{~cm}$ high) and smaller ( $13.5 \mathrm{~cm} \mathrm{high),} \mathrm{with} \mathrm{a} \mathrm{wide} \mathrm{mouth} \mathrm{and} \mathrm{cylindrical} \mathrm{form} \mathrm{(Dąbal} \mathrm{2008:} \mathrm{236).}$

Vessels of similar shape, but made of faience, were excavated at the Ducal Castle in Szczecin. Their earliest possible date is the second half of the 17 th century, but according to the author it is more probable that they come from the i8th century (Cnotliwy 20I4: 287).

The archaeological collection of the Museum of Warsaw also contains a stoneware jar related to pharmacy from the i8th century. It is a cylindrical vessel with a diameter of just over $10 \mathrm{~cm}$ and a height of nearly $20 \mathrm{~cm}$. It was found in the so-called Saxon Wing of the Royal Castle in Warsaw. ${ }^{2}$

2 The specimen is currently on display in the Royal Castle. 
Ioo | Ewelina Więcek-Bonowska

In Germany, analogous vessels are known, inter alia, from Leipzig; they were studied and published by Ralf von Kluttig-Altmann, and are called "standing vessels" in his work. The author mentions that these large vessels could have decorative functions, standing in rows on large pharmacy shelves. The vessels from Leipzig are made of stoneware, their height is $12 \mathrm{~cm}$ or more, they are "conical or cylindrical" in shape (Klutting-Altmann 2006: 325).

The jars presented in Josef Horschik's book are also a kind of analogy. These are vessels of similar dimensions and shape to the jars from the Saski Palace. However, the decorations of these vessels have a different character (Horschik 1978: 326, 330, 332).

It seems, however, that the closest analogy to jars from the Saxon Palace are square glass bottles from the travelling pharmacy of Augustus II, precisely dated and inscribed with the "AR" monogram. The portable pharmacy was transported in five iron-reinforced chests, each almost one metre long; during transport they were supervised by the King's personal physician and a pharmacist (Syndram 1997: 369; Szelegejd 2007: 46). One of the sides the bottles is decorated with an enamel-painted royal coat of arms: a crowned ermine mantle with coats of arms of Poland and Saxony and the "AR" monogram of the ruler. Below, there is the date 1719 and a band with Latin names of medical products. The vessels from the collection of the Kunsgewerbesmuseum in Dresden and the National Museum in Warsaw bear the inscriptions: "AQV:CARD:BEN", 3 "OL:JUNIPER" 4 and "SP:TARTAR" (Wolfgang-Hagen and Heinrici 1996: 34-35, Fig. I, 2; Syndram 1997: 369, No. XI 67). Another similar glass bottle, currently in the collection of the King John III Palace Museum in Wilanów, bears the inscription "AQV:FUMAR", ${ }^{6}$ which means that it contained a therapeutic extract of the common fumitory, Fumaria officinalis (Szelegejd 2007: 46-47).

These specimens are made of different material (glass), yet in terms of form and purpose they are closely related to the jars found in the Saxon Palace. They are also associated with the Saxon court. However, it should be noted that the above-mentioned glass bottles are more decorative; they had to be clearly marked to be easily recognizable as part of the travelling pharmacy.

A similar drug jar from the court pharmacy of another Wettin ruler - Augustus III (King of Poland between 1733 and 1763) - is now in the collection of the Smithsonian Institution in Washington (Roeske 1991: 170, Fig. I28). It is a cylindrical ceramic vessel decorated with painted coats of arms of Poland and Saxony with the "AR" monogram and the date 1734 .

\footnotetext{
Aqua cardui benedicti, i.e., blessed thistle water.

Oleum juniperi, i.e., juniper oil.

Spiritus tartari, i.e., tartaric acid.

Aqua fumaria.
} 
Stoneware Jars from the I8th Century from the Saxon Palace in Warsaw $\mid$ IOI

\section{INTERPRETATION}

The excavated specimens are undoubtedly connected with a pharmacy. It may be assumed that the stoneware jars found in the Saxon Palace were used to store medicines, probably dry substances. This is indicated by the shape of the vessels, especially their mouths. Wide mouths made it easier to fill the jars with loose substances and measure required amounts of them. The material itself was equally important - stoneware is hard, impermeable and resistant to mechanical damage.

Ceramic pharmacy containers ${ }^{7}$ had a similar shape. However, as pointed out by W. Roeske, they had a differently-shaped rim (straight) and were covered with a lid, whereas glass apothecary jars had a flaring rim, which made it possible to cover the containers with animal membranes, fabric or parchment (Fig. 2; Roeske 1973: 27).

The stoneware vessels from the Saxon Palace are medium-sized; their characteristic appearance (square cross-section) and large, legible royal monograms suggest that they had not only utilitarian functions, but could also have been used for decorative purposes.

The decoration and size of pharmacies changed in the early modern period. They no longer consisted of one room and became much more extensive: apart from the front (main) chamber, there were also other rooms, including a laboratory. In the front room, customers were served. It was also used to store and distribute ready-made medicines and various goods sold in pharmacies at that time (e.g., spices, wax, paper, wine). Therefore, these chambers had to be adequately furnished, e.g., with ornate storage vessels, which were displayed on shelves behind the serving counter, within sight of customers (Figs 3, 4; cf., Roeske i991: 97-99).

As mentioned earlier, the jars from the Saxon Palace bear the royal monogram "AR" (abbreviation of "Augustus Rex"). Apothecary vessels were often decorated with the coats of arms or emblems of aristocratic families, customers of a given pharmacy; it enhanced the prestige of the pharmacist, boasting of a wealthy clientele (Roeske 1973: I0). However, in the case of the jars from the Saxon Palace, the crowned monograms were probably ownership marks: it may be assumed that the vessels were made by special order of the King. They presumably come from the pharmacy catering mainly for the ruler, his family and court, located on the premises of the Saxon Palace. This hypothesis is confirmed by the similarity of their form and decorative motives to glass bottles from the travelling pharmacy of Augustus II and to ceramic vessels from the pharmacy of Augustus III.

If the excavated specimens were made for a pharmacy located in the Saxon Palace in Warsaw, they were probably manufactured after 1724. It was only then that Augustus II and his court moved to the new residence; previously the King stayed at the Royal Castle in Warsaw (Borowska 2020: 44). It is less probable that they were manufactured after 1763 (the date of the death of Augustus III; Staszewski 1989: 277). At that

7 Containers of other materials, e.g., wood, were also used. 
I02 | Ewelina Więcek-Bonowska

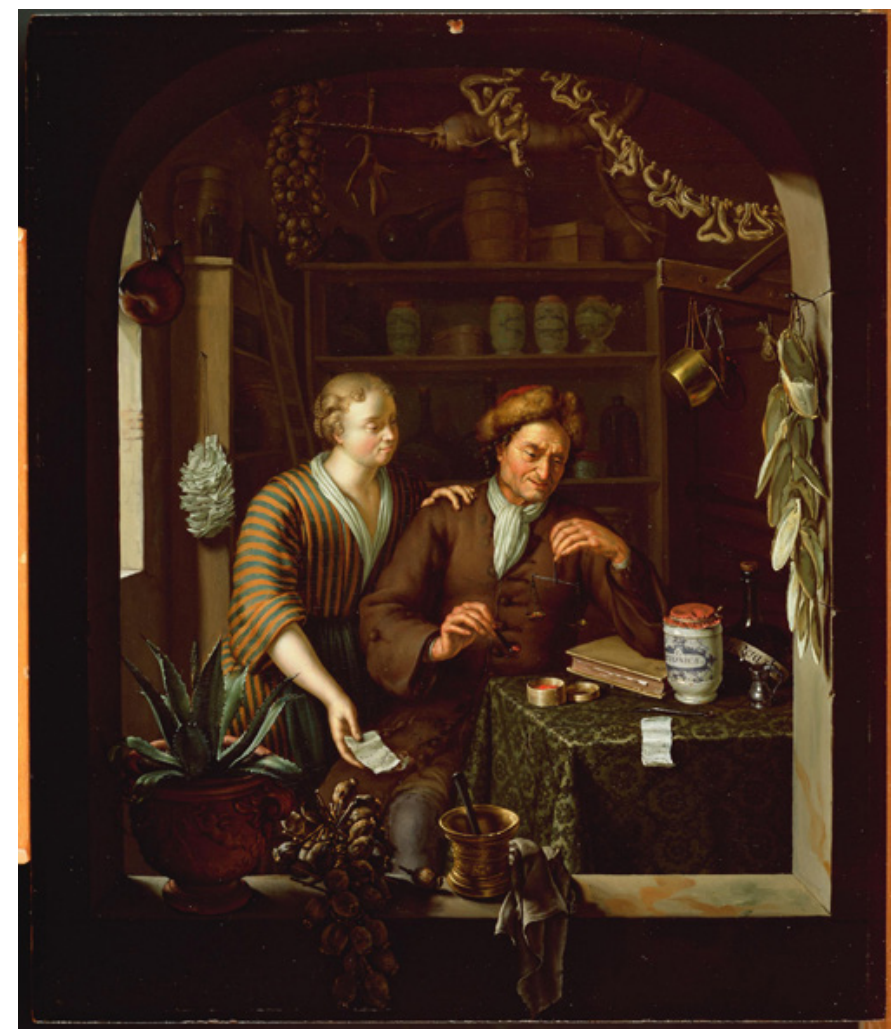

Fig. 3 The Apothecary, Frans van Mieris, 1714, collection of the Amsterdam Museum. In the foreground, a jar covered with parchment or leather. Source: Wikimedia Commons, public domain.

time the palace changed its role. Although it remained in the hands of the Electors of Saxony, they used only a small part of the main building as an accommodation for their diplomatic and trade missions. The rest of the palace was divided into smaller sections, rented as offices and private apartments. It is possible that the pharmacy was still operating, but it is doubtful that new batches of storage vessels marked with the royal monogram were ordered for it (Borowska 2020: II4). In 1797, the palace was purchased by the King of Prussia, Frederick William II, and ceased to have a residential function. It appears that the pharmacy also ceased to exist at that time (if it had not been closed earlier, after the death of Augustus III).

The jars from the Saxon Palace, made at the request of the Wettin rulers of Poland, were probably manufactured in Waldenburg (a famous stoneware production centre 


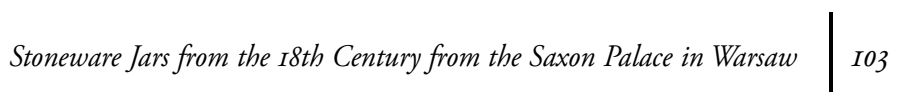

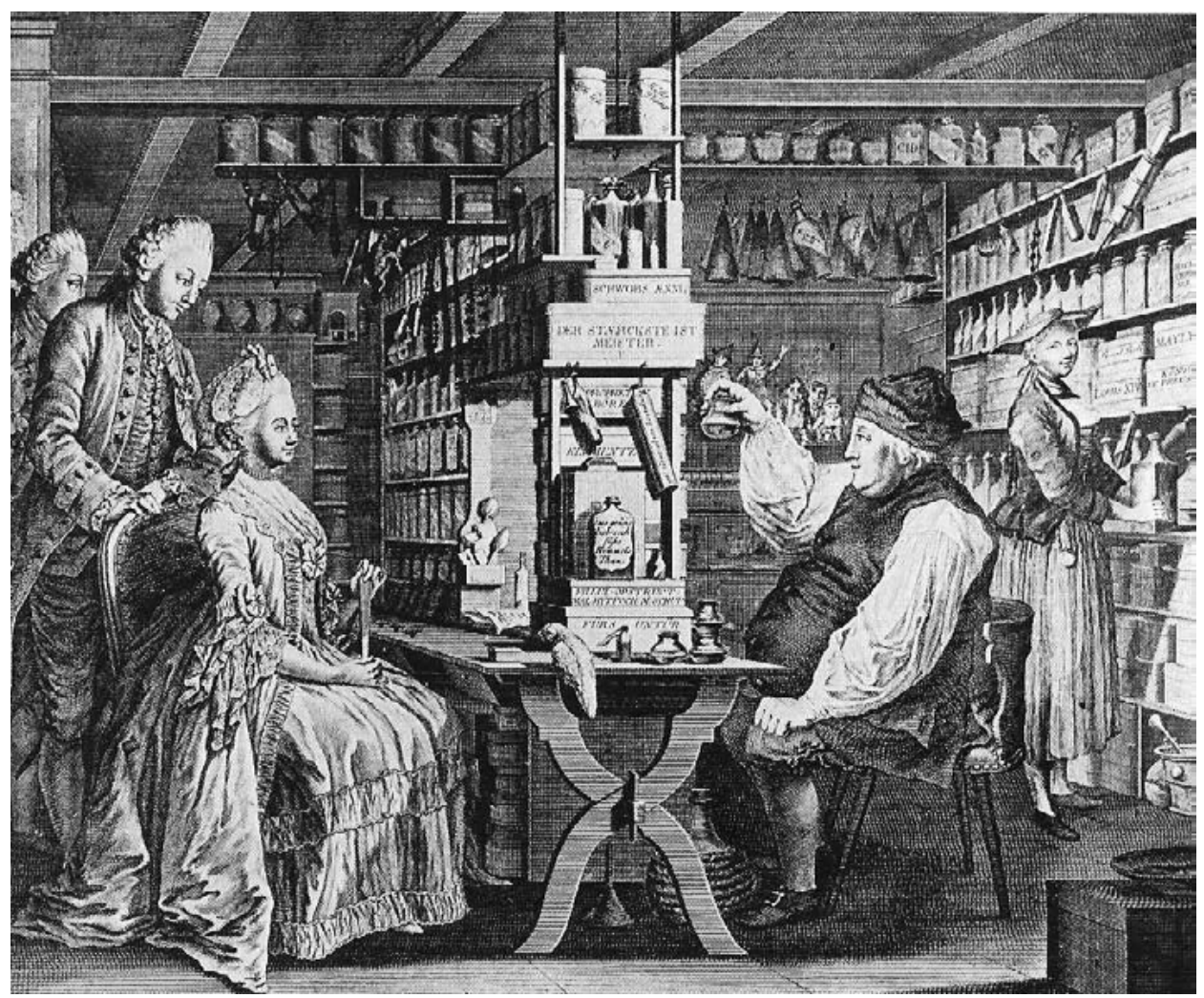

Fig. 4. Country Pharmacy, print showing French aristocratic customers at Michael Schüppach's pharmacy on the Dorfberg in Langnau in Switzerland. Author G. Locher (1774), engraver Bartholomäus Hübner (1775). Source: Wikimedia Commons, public domain.

in Baden-Württemberg) or in an unspecified manufactory in Saxony. ${ }^{8}$ Waldenburg produced large stoneware vessels for pharmaceutical and chemical companies (see, for example, Kowalczyk 20I4: 3I).

Little is known about the pharmacy itself. Its existence is confirmed for example by a periodical published in the Polish capital at that time - Gazeta Warszawska (Gazeta Warszawska 1795, No. IO-I2), which reported that it used to be located in the Saxon Palace (Wenda I9I7: 23). It is also mentioned in Materiaty do dziejów farmacji $w$ dawnej Polsce (Świeżawski and Wenda I887: IIO). According to K. Wenda the

8 Bernd Brinkmann, oral communication (October 24, 2020). 
I04 $\mid$ Ewelina Więcek-Bonowska

simultaneous existence of the Royal Pharmacy ${ }^{9}$ in the vicinity of the Royal Castle in Warsaw (in the building beside the Cracow Gate) suggests that the pharmacy located in the Saxon Palace must have been a court (private) pharmacy of the Saxon Electors (Wenda 1917: 23).

Around 1719, Augustus II began to show alarming symptoms; the present state of medical knowledge makes it possible to interpret them - the King suffered from diabetes (Widacka 20IO). He had a number of ailments accompanying this disease, so it can be assumed that he required medicaments and services of a team of medical professionals, including physicians and pharmacists. His travelling pharmacy contained the drug described as "AQV:CARD:BEN" (Aqua cardui benedicti), i.e., blessed thistle water made from the Cnicus benedictus plant. It was used as a supplementary medicine to cure fevers of unknown origin; it was recommended to "add a few drops [of it] to vodka" (Compendium Medicum I725: 429). Tartaric acid was used to treat "the warming of the liver" (Compendium Medicum 1725: 268). Juniper oil was used, as it is today, as a disinfectant. Juniper oil might have been used to treat the left foot of Augustus II, gangrenous due to diabetes ravaging his body for many years (Widacka 20IO).

The existence of a court pharmacy in the Saxon Palace is also confirmed by other archaeological evidence. Apart from the described jars, a set of standard, i8th-century glass apothecary vessels was excavated. They are bottles, jars and vials of various sizes and shapes (called zakonniczki in Polish archaeological studies) and an ampoule (Fig. 5; cf., Majewski 20I8: I60).

Moreover, at the site of the Saxon Palace, a stoneware measuring vessel was found (Fig. 6; cf., Klutting-Altmann 2006: 324; Dąbal et al., 2018a: 180, Fig. 2); stoneware mineral water bottles were also discovered (Fig. 7). A similar set of stoneware mineral water bottles from Höxter was described by Bernd Brinkmann (2020).

It remains an open question whether the pharmacy in the Saxon Palace served the royal court only. It is difficult to provide an unequivocal answer to this question because of the lack of relevant written sources. The Saxon rulers did not live permanently in Warsaw and visited the Polish capital occasionally (Źórawska-Witkowska 1997: 57-6I). If the pharmacy had been open only during the presence of the royal court, it would be completely unprofitable. The Royal Pharmacy near the Royal Castle in Warsaw, apart from preparing medicines for the ruler and his court, also catered for other inhabitants of Warsaw and guests from outside the city. It is known for example from contemporary correspondence that Countess Elżbieta Sieniawska usually obtained medicines from the Royal Pharmacy in Warsaw (Łojek 196r: 46; Słaby 20I4: 243).

It cannot be ruled out that the pharmacy in nearby Trębacka Street in Warsaw, which was still operating at the beginning of the 2oth century and had a signboard

9 For more about the excavations at the site of the Royal Pharmacy in Warsaw, see: Więcek E. 20I7; Więcek M. 20I7; Kozłowska and Nowakowski 1987. 

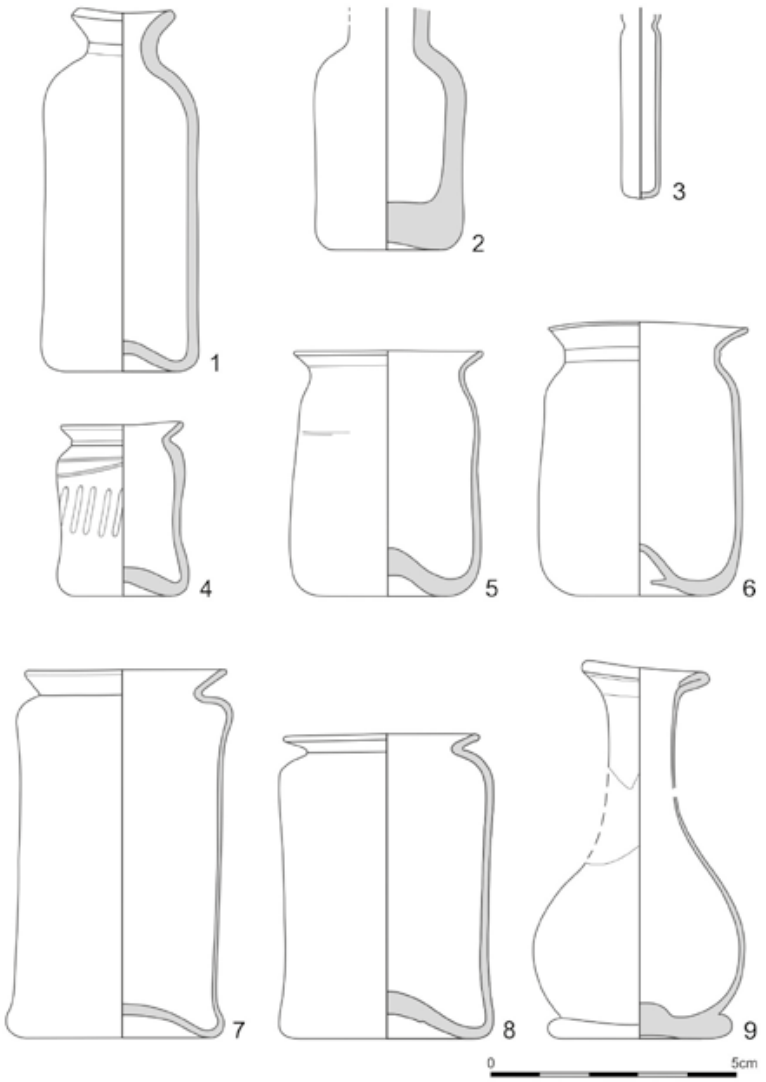

Fig. 5. Selected glass vessels from the court pharmacy in the Saxon Palace in Warsaw. 1, 2- bottles; 3-ampoule; 4-8 jars; 9 - vial, so-called zakonniczka. Drawing by U. Skwara-Nieckuła.

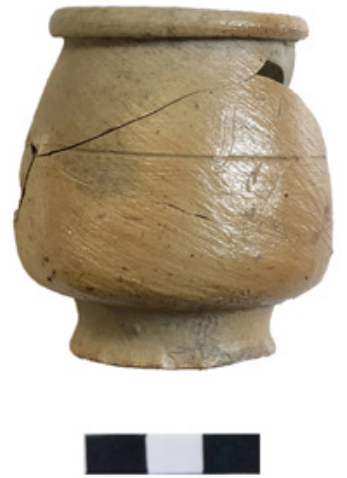

Fig. 6. Stoneware measuring vessel found on the site of the Saxon Palace in Warsaw.

Photo by E. Więcek-Bonowska. 
Io6 |Ewelina Więcek-Bonowska

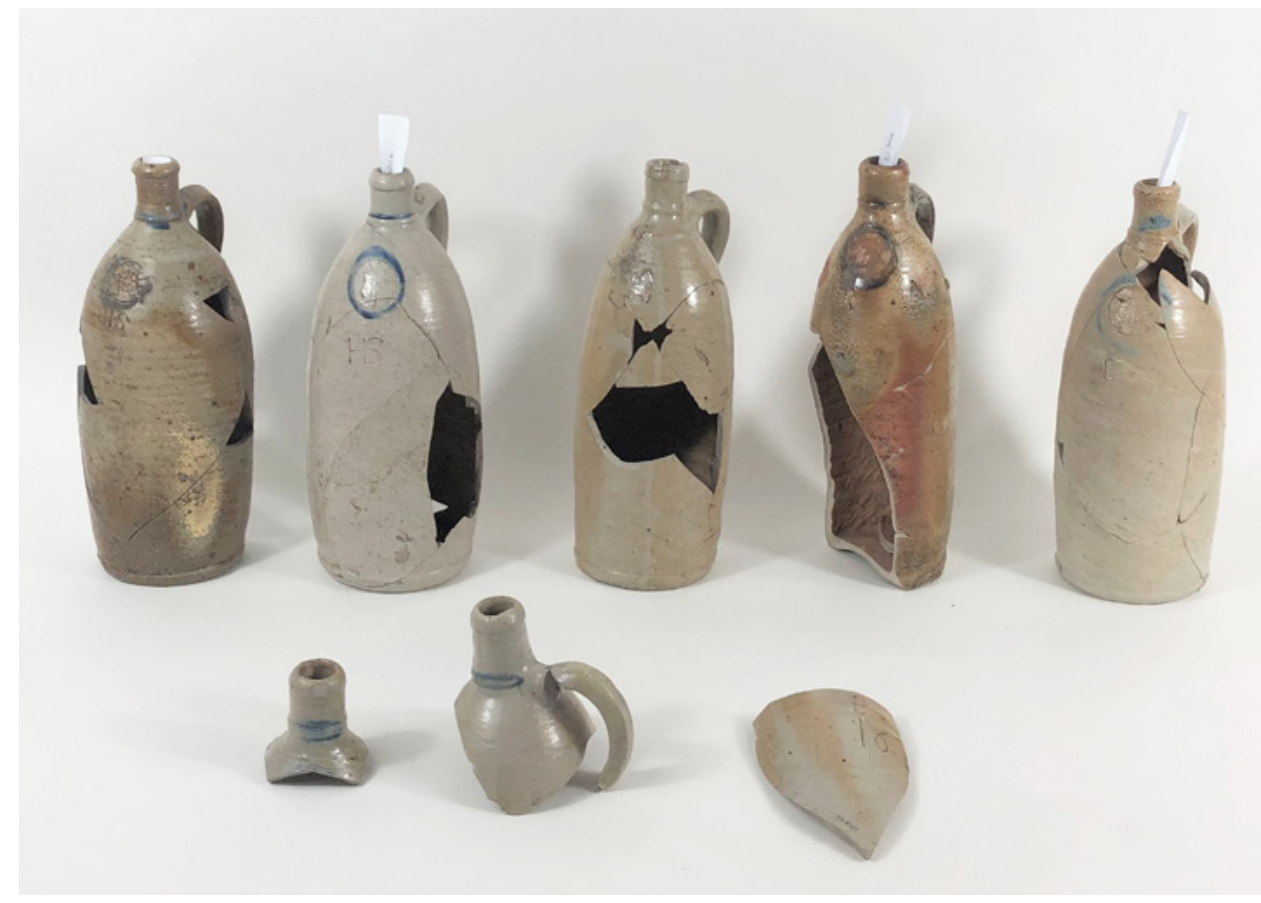

Fig. 7. Stoneware mineral water bottles found on the site of the Saxon Palace in Warsaw, height $-27-29 \mathrm{~cm}$. Photo by E. Więcek-Bonowska.

"Pharmacy to His Royal Majesty's Court" was the legacy of the court pharmacy of the Saxon Electors (Wenda 1917: 23).

\section{CONCLUSIONS}

The number of Polish studies devoted to modern stoneware drug jars is limited. So far, mostly glass apothecary vessels have been discussed; ceramic containers related to pharmacy have rarely been researched. It is necessary to publish more newly-discovered material relics of modern pharmacy. The present article presents only a small fraction this subject, connected with a unique set of apothecary jars made specially for the royal Saxon court. The results, combined with those contained in previously published works devoted to the archaeology of pharmacy, will facilitate a more detailed analysis of stoneware apothecary jars in the city of Warsaw before the partitions of Poland. 


\section{REFERENCES}

Borowska, J. 2009. Opowieści z Patacu Saskiego. Warszawa.

Borowska, J. 20II-20I2. Życie codzienne w pałacu Saskim w Warszawie w XVIII wieku w świetle wykopalisk archeologicznych. Z Otchtani Wieków 66(I-4): I00-I09.

Borowska, J. 20I8. Pałac Saski w świetle badań archeologicznych. Skarpa Warszawska 4(I09): I4-2I.

Borowska, J. 20I9a. Pałac Saski. Skarpa Warszawska I(II8): 8-9.

Borowska, J. 20I9b. Pałac Brühla. Skarpa Warszawska 2(II9): 8-9.

Borowska, J. 2019c. Kamienica Malhomme'a. Skarpa Warszawska 7(I24): 8-9.

Borowska, J. 2020. Niezwykta historia Patacu Saskiego. Warszawa.

Brinkmann, B. 2020. Der Mineralwasserkonsum auf dem Adelshof Heisterman von Ziehlberg in Höxter im I8. Jahrhundert, dokumentiert nach Grabungsfunden aus einer Kloake. Mülheim an der Ruhr.

Cędrowski, R. 2006. Badania archeologiczno-architektoniczne na terenie Patacu Saskiego w Warszawie, przeprowadzone w okresie 27 sierpnia do 22 grudnia 2006 roku. Warszawa. Typescript in the Archaeological Research Laboratory of the Museum of Warsaw.

Cędrowski, R. 2007. Badania wykopaliskowe na terenie Pałacu Saskiego w Warszawie. Mazowiecki Rocznik Konserwatorski 2, I29-134.

Cędrowski, R. 2008. Badania archeologiczno-architektoniczne przeprowadzone na Placu Józefa Pitsudskiego $w$ Warszawie, na terenie zespotu dawnych kamienic przy ul. Królewskiej. Warszawa. Typescript in the Archaeological Research Laboratory of the Museum of Warsaw.

Cnotliwy, E. 20I4. Archeologia Zamku Książą Pomorskich w Szczecinie. Szczecin.

Dąbal, J. 2008. An attempt to recreate the ceramic vessel selection/Próba odtworzenia asortymentu naczyń ceramicznych. In W. Ossowski (ed.), The General Carleton Shipwreck, I785/ Wrak statku General Carleton, 1785, 223-234. Gdańsk.

Dąbal, J. 20I2. Naczynia kamionkowe na stołach w XVI i XVII wieku. Wybór źródeł pozyskanych w efekcie badań archeologicznych. In B. Możejko (ed.), Historia naturalna jedzenia. Między antykiem a XIX wiekiem, I46-I63. Gdańsk.

Dąbal, J. 2015. Wyroby ceramiczne. In J. Dąbal, K. Krawczyk and T. Widerski (eds), Gdańsk. Twierdza Wistoujście. Badania archeologiczno-architektoniczne w latach 20I3-20I4, 22I-264. Gdańsk.

Dąbal, J. 20I8. Naczynia ceramiczne lokalnej produkcji oraz importowane, użytkowane od XVI do XIX wieku. In A. Pudło, W. Ossowski and E. Trawicka (eds), Jatki mięsne w Gdańsku od XIV do XX wieku, 30I-332. Gdańsk.

Dąbal, J., Kubus, R. and Szczepanowska, K. 20I8a. Ceramiczne i szklane słoiki do przechowywania maści z badań archeologicznych w Gdańsku. Medycyna Nowożytna 24(3): 173-190.

Dąbal, J., Szczepanowska, K. and Kubus, R. 20I8b. Higiena i zdrowie w świetle źródeł materialnych. In J. Dąbal (ed.), Domy i ich mieszkańcy w świetle badań archeologiczno-architektonicznych przy ulicy Świętojańskiej 6-7 w Gdańsku, 239-250. Gdańsk.

Horschik, J. 1978. Steinzeug I5. bis I9. Jahrhundert. Von Bürgel bis Muskau. Dresden.

Klarecki, M. 2008. Zabytkowa ceramika z wykopalisk pod Pałacem Saskim. Spotkania z zabytkami 2(252): $37-38$.

Klarecki, M. 20I7. Pozostałości z osiemnastowiecznych serwisów warszawskich dworów królewskich, Kwartalnik Historii Kultury Materialnej 65(2): 197-208. 
I08 $\mid$ Ewelina Więcek-Bonowska

Kluttig-Altman, R. 2006. Von der Drehscheibe zum Scherbenhaufen. Leipziger Keramik des I4. bis I8 Jahrhunderts im Spannungsfeld von Herstellung, Gebrauch und Entsorgung. Dresden.

Kowalczyk, A. 20I4. Naczynia kamionkowe z Poznania w póżnym średniowieczu i czasach nowożytnych. Poznań.

Kowalczyk, J. 1997. Dwie stolice - Drezno i Warszawa. In Pod jedna korona. 30o-lecie Unii Polsko-Saskiej. Kultura i sztuka w czasach Unii Polsko-Saskiej, 37-4I. Warszawa.

Kozłowska, R. and Nowakowski, A. 1987. Szkło apteczne z badań archeologicznych Apteki Królewskiej w Warszawie. Acta Universitatis Nicolai Copernici. Archeologia I2. Archeologia Szkta 2: I23-I4I.

Łojek, J. 196r. Strusie króla Stasia. Warszawa.

Majewski, M. 20I8. Szkło apteczne z badań archeologicznych w Stargardzie (XVII-pocz. XIX w.). In J. Nieznanowska (ed.), Aptekarskie drogi do wolności, I57-168. Szczecin-Stargard.

Matějková, K. 20I8. Keramikfunde aus der Latrine des Theatinerklosters auf der Kleinseite in Prag. In H. Stadler and L. Obojes (eds), Keramik zwischen Werbung, Propaganda und praktischem Gebrauch. Beiträge vom 5o. Internationalen Symposium für Keramikforschung in Innsbruck 20I7, Nearchos 23, 273-288. Innsbruck.

Roeske,W. 1973. Polska ceramika apteczna w Muzeum Farmacji A. W. w Krakowie. Kraków.

Roeske, W. 1991. Polskie apteki. Wrocław-Warszawa-Kraków.

Słaby, A. 20I4. Rządzicha Oleszycka. Dwór Elżbiety z Lubomirskich Sieniawskiej jako przyktad patronatu kobiecego w czasach saskich. Kraków.

Staszewski, J. 1989. August III Sas. Wrocław.

Świeżawski, E. D. and Wenda, K. I887. Materyjaty do dziejów farmacji w dawnej Polsce III. Warszawa.

Szelegejd, B. 2007. Szkto europejskie. Galeria rzemiosta artystycznego. Warszawa.

Syndram, D. 1997. Sztuka na dworze Augusta Mocnego w Dreźnie. In Pod jedna korona. 300-lecie Unii Polsko-Saskiej. Kultura i sztuka w czasach Unii Polsko-Saskiej, 335-375. Warszawa.

Wenda, K. 1917. Apteka na zamku warszawskim i aptekarze królewscy. Karta z dziejów Warszawy. Warszawa.

Widacka, H. 20ı. Choroba i śmierć króla Augusta II. Silva Rerum, https://www.wilanow-palac.pl/ choroba_i_smierc_krola_augusta_ii.html (accessed II.02.202I).

Wieczorkowicz, A. 1752. Compendium Medicum Auctum To iest Krotkie Zebranie y opisanie Chorob, Ich różności, przyczyn, znaków, sposobow do leczenia, Także rożnych sposobow do robienia Wodek, Oleykow, Julepow, Syropow, Konfitur, Maści, Plastrow \&́c. y rożnych osobliwych rzeczy: Na Siedm Traktatow Rozdzielone. Częstochowa.

Więcek, E. 20I2. Kuchnia i jadalnia zamożnych mieszkańców XVIII-wiecznej Warszawy. Warszawskie Materiaty Archeologiczne 10: 88-I09.

Więcek, E. 20I7. Butelki kamionkowe znalezione na terenie Apteki Królewskiej w Warszawie. Kwartalnik Historii Kultury Materialnej 65(3): 33I-342.

Więcek, M. 2017. Materiał szklany z zakresu archeologii farmacji z Apteki Królewskiej oraz terenu placu Zamkowego. In Z. Polak and K. Meyza (eds), Między miastem a dworem. Badania archeologiczne placu Zamkowego w Warszawie w latach 1977-1983, 237-258. Warszawa, Archeologia Dawnej Warszawy 4(2).

Wolfgang-Hagen, H. and Heinrici, A. 1996. Die Glasflaschen der Reiseapotheke Augusts des Starken, Geschichte der Pharmazie 3: 33-36.

Żórawska-Witkowska, A. 1997. Pobyty dworu królewskiego w Polsce. In Pod jedna korona. 30o-lecie Unii Polsko-Saskiej. Kultura i sztuka w czasach Unii Polsko-Saskiej, 57-6I. Warszawa. 